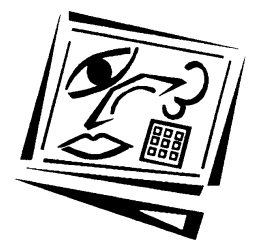

\title{
The "third"-order barrier for technology-integration instruction: Implications for teacher education
}

\author{
Chin-Chung Tsai \\ National Taiwan University of Science and Technology \\ Ching Sing Chai \\ Nanyang Technological University
}

\begin{abstract}
Technology integration is a major trend in contemporary education practice. When undertaking technology integration in classrooms, a first-order barrier and a secondorder barrier, as proposed by Ertmer (1999), can hinder its implementation. The firstorder barrier is external, such as lack of adequate access, time, training and institutional support. The second-order barrier includes teachers' personal and fundamental beliefs such as teachers' pedagogical beliefs, technology beliefs, willingness to change. This paper argues that the lack of design thinking by teachers may be the "third"-order barrier for technology integration.
\end{abstract}

In 1999, Ertmer proposed a framework elaborating first-order barriers and secondorder barriers for technology integration in education. The first-order barrier includes some external factors that may constrain integration, such as lack of adequate access, time, training and institutional support. These factors are extrinsic to teachers. The second-order barrier, which is more intrinsic to teachers, includes teachers' pedagogical beliefs, technology beliefs, and teachers' willingness to change; these are teachers' personal beliefs that may hinder the implementation of technology integration in classrooms.

In the last decade, educational researchers have conducted extensive research work in investigating or enhancing teachers' competence of using technology (e.g., Kim, Jung \& Lee, 2008), addressing the first-order barrier. Also, some studies have been undertaken for the second-order barrier. For example, Mueller, Wood, Willoughby, Ross and Specht (2008) explored the relationships between teachers' technology integration and their beliefs supporting the use of computers as an instructional tool. The research work about teachers' conceptions of teaching for technology-enhanced learning environments (Ellis, Steed \& Applebee, 2006; Gonzalez, 2009, 2010) can also be categorised as exploring the possible second-order barriers expressed by the teachers. In recent years, research efforts have been devoted to exploring teachers' technological pedagogical content knowledge (TPACK) (Chai, Koh, Tsai \& Tan, 2011; Lee \& Tsai, 2010; Mishra \& Koehler, 2006). The TPACK framework, however, addresses the issues related to ICT integration from a knowledge perspective. It implies that if teachers develop associated TPACK, many issues can be resolved. To a certain extent, technology integration issue can be resolved if teachers possess stronger TPACK capacity. 
However, further investigations about how TPACK is associated with teachers' beliefs and how teachers overcome contextual challenges through creative re-structuring of classroom learning environment are needed (Voogt, Fisser, Pareja Roblin, Tondeur \& van Braak, in press). We would like to highlight that the key essence of TPACK lies in the dynamic creation of knowledge and practice by teachers when they are confronted with the advancement of ICT and its associated pedagogical affordances. We term this capacity as "design thinking". It moves beyond the TPACK knowledge perspective, which tends to be associated with codified/justified true beliefs, into the design mode of knowing. Design thinking seeks to change and improve current situations and create what is desired. It may therefore tackle both first and second order barriers as it treats all barriers as problems that need to be tackled and resolved through human creative thinking.

The three research reports from developing countries in this special issue indicate that most of them explore the first-order barrier for technology integration. For instance, Lim and Pannen (2012, in this issue) mention the lack of funding and staff support in the case study from Indonesia; Yan, Xiao and Wang (2012, in this issue) highlight the acquisition of cutting-edge technologies in teacher education courses in China; Dionys (2012, in this issue) from Cambodia addresses the lack of digital resources and infrastructure (e.g., the unstable electricity support) for technology integration in teacher training centres. However, as Ertmer (1999) rightly pointed out, even if the teachers have sufficient competence, facility and support for technology, classroom integration does not necessarily follow. Resolving first order barriers is more than purchasing and possessing hardware and software. Schools that centralise their ICT facilities in computer laboratories may well learn that teachers are still not using them because of the clash in timetabling and tedious booking procedures. In other words, formulating procedures and creating facilitating conditions for easy and timely access are crucial for the maximisation of use and this involves careful design thinking.

To achieve technology integration, the second-order barrier also needs to be overcome. Certainly, the authors of the short research reports mentioned some related ideas about the second-order barrier. Some ideas about TPACK are used in Dionys' study, and the study also concludes by highlighting the challenge of teachers' attitude change towards instructional approaches. Yan, Xiao and Wang try to incorporate inquirybased learning in teacher education courses, strengthening the pedagogical foundation for technology integration. Lim and Pannen (2012) also try to link ICT competence and pedagogical consideration when evaluating teacher education programs. However, deeply rooted beliefs can prove to be hard to detect, and unless deep changes are effected, the programs may teach the skills and knowledge but still fail to produce the necessary shift in pedagogy (see Lim \& Chai, 2008). This again calls for insightful design by teacher educators.

This position paper thus raises a further question: if both first-order and second-order barriers have been removed, will technology integration happen? We would argue that at least one more barrier should be discussed, that is, the teachers' design thinking. If a teacher has sufficient facility, rich digital instructional resources, positive attitudes or strong beliefs toward technology integration, he/she may not have successful implementation. As classroom context and students are quite dynamic, the teacher should rely on some design thinking to re-organise or create learning materials and activities, adapting to the instructional needs for different contexts or varying groups of learners. This perspective has been highlighted by Tsai et al. (in press). Currently, the 
enhancement of design thinking for teachers is not a major component of teacher education programs. The lack of design thinking skills and disposition may be the "third"-order barrier for technology integration.

The removal of the first-order barrier may facilitate the usage of technology by teachers. If the second-order barrier has been eliminated, the teachers may be committed to implement technology integration in classrooms. In such stage, they may utilise technology at any time and any place. Through reducing the third-order barrier, teachers can undertake technology integration actively and fluently. By achieving this, teachers can use technology for instruction at the right time and right place. Hence, technology integration in education is not simply as a state of "technology", rather, it becomes a state of "art". In addition, the cultivation of design thinking should be an ongoing effort, regardless of whether or not one is in a technology rich or poor environment. Barriers will always exist in one form or another and design capacity is usually sharpened in a constrained environment. Building teachers' / educators' design capacity is therefore arguably the most crucial task for further integration of technology in education.

\section{References}

Chai, C. S., Koh, J. H. L., Tsai., C.-C. \& Tan, L. L. W. (2011). Modeling primary school pre-service teachers' technological pedagogical content knowledge (TPACK) for meaningful learning with information and communication technology (ICT). Computers $\mathcal{E}$ Education, 57, 1184-1193. http:/ / dx.doi.org/10.1016/j.compedu.2011.01.007

Dionys, D. (2012). Introduction of ICT multimedia into Cambodia's teacher training centres. In C. P. Lim \& C. C. Chai (Eds), Building the ICT capacity of the next generation of teachers in Asia. Australasian Journal of Educational Technology, 28(Special issue, 6), 1068-1073. http: / / www.ascilite.org.au/ajet/ajet28/dionys.html

Ellis, R. A., Steed, A. F. \& Applebee, A. C. (2006). Teacher conceptions of blended learning, blended teaching and associations with approaches to design. Australasian Journal of Educational Technology, 22(3), 312-335. http:/ / www.ascilite.org.au/ajet/ajet22/ ellis.html

Ertmer, P. A. (1999). Addressing first- and second-order barriers to change: Strategies for technology integration. Educational Technology Research and Development, 47(4), 47-61. http: / / dx.doi.org/10.1007/BF02299597

Gonzalez, C. (2009). Conceptions of, and approaches to, teaching online: A study of lecturers teaching postgraduate distance courses. Higher Education, 57(3), 299-314. http: / / dx.doi.org/10.1007/ s10734-008-9145-1

Gonzalez, C. (2010). What do university teachers think eLearning is good for in their teaching? Studies in Higher Education, 35(1), 61-78. http: / / dx.doi.org/10.1080/ 03075070902874632

Kim, J. H., Jung, S. Y. \& Lee, W. G. (2008). Design of contents for ICT literacy in-service training of teachers in Korea. Computers \& Education, 51(4), 1683-1706. http:/ / dx.doi.org/10.1016/j.compedu.2008.05.001

Lee, M.-H. \& Tsai, C.-C. (2010). Exploring teachers' perceived self efficacy and technological pedagogical content knowledge with respect to educational use of the World Wide Web. Instructional Science, 38(1), 1-21. http: / / dx.doi.org/10.1007/ s11251-008-9075-4

Lim, C. P. \& Chai, C. S. (2008). Teachers' pedagogical beliefs and their planning and conduct of computer-mediated classroom lessons. British Journal of Educational Technology, 39(5), 807-828. http: / / dx.doi.org/10.1111/j.1467-8535.2007.00774.x 
Lim, C. P. \& Pannen, P. (2012). Building the capacity of Indonesian education universities for ICT in pre-service teacher education: A case study of a strategic planning exercise. In C. P. Lim \& C. C. Chai (Eds), Building the ICT capacity of the next generation of teachers in Asia. Australasian Journal of Educational Technology, 28(Special issue, 6), 1061-1067. http: / / www.ascilite.org.au/ajet/ajet28/lim-cp.html

Mishra, P. \& Koehler, M. J. (2006). Technological pedagogical content knowledge: A framework for teacher knowledge. Teachers College Record, 108(6), 1017-1054. http: / / www.tcrecord.org/ Content.asp?ContentID=12516

Mueller, J., Wood, E., Willoughby, T., Ross, C. \& Specht, J. (2008). Identifying discriminating variables between teachers who fully integrate computers and teachers with limited integration. Computers $\mathcal{E}$ Education, 51(4), 1523-1537. http: / / dx.doi.org/10.1016/j.compedu.2008.02.003

Tsai, C.-C., Chai, C.-S., Wong, B. K. S., Hong, H. Y. \& Tan, S. C. (in press). Positioning design epistemology and its applications in education technology. Educational Technology and Society.

Voogt, J., Fisse, P., Pareja Roblin, N., Tondeur, J. \& van Braak, J. (in press). Technological pedagogical content knowledge - a review of the literature. Journal of Computer Assisted Learning. http:/ / dx.doi.org/10.1111/j.1365-2729.2012.00487.x

Yan, H., Xiao, Y. \& Wang, Q. (2012). Innovation in the educational technology course for preservice student teachers in East China Normal University. In C. P. Lim \& C. C. Chai (Eds) Building the ICT capacity of the next generation of teachers in Asia. Australasian Journal of Educational Technology, 28(Special issue, 6), 1074-1081. http: / / www.ascilite.org.au/ajet/ajet28/yan.html

Authors: Chin-Chung Tsai, Chair Professor

Graduate Institute of Digital Learning and Education

National Taiwan University of Science and Technology

No.43, Sec. 4, Keelung Road, Da'an District, Taipei City 106, Taiwan.

Email: cctsai@mail.ntust.edu.tw

Dr Ching Sing Chai, Associate Professor

Learning Sciences \& Technologies, National Institute of Education

Nanyang Technological University, 1 Nanyang Walk, Singapore 637616.

Email: chingsing.chai@nie.edu.sg

Please cite as: Tsai, C.-C. \& Chai, C. S. (2012). The "third"-order barrier for technologyintegration instruction: Implications for teacher education. In C. P. Lim \& C. S. Chai (Eds), Building the ICT capacity of the next generation of teachers in Asia. Australasian Journal of Educational Technology, 28(Special issue, 6), 1057-1060. http: / / www.ascilite.org.au/ajet/ajet28/tsai-cc.html 